\title{
IMPLEMENTASI KEPEMIMPINAN TRANSFORMASIONAL KEPALA SEKOLAH DASAR NEGERI
}

\author{
Renita Silvia Rahayu \\ Rumah Sakit Prima Husada \\ Banjararum Selatan No. 3 Mondoroko Singosari Malang \\ email: renita.7171@gmail.com
}

\begin{abstract}
This study aims to describe the characteristics of implementation of transformational leadership of principals, supporting factors, and inhibitors and solutions in SDN Percobaan 1 Malang. This study used a qualitative approach with case study design. Data collection techniques used are observation, interview and documentation. The results of this study; (1) Characteristics of Transformational Leadership Implementation; (a) idealizing the influence of being a good example and fostering pride for the citizens of the school, (b) inspirational motivation that is able to raise the spirit, give attention, and trust for the citizens of the school, (c) intellectual consideration is to give self-esteem for creative teachers and allowing the citizens of the school to solve the problem, (d) intellectual stimulation involving teachers and staff in training, and executing class visit supervision. (2) Supporting factors are the ability of teachers and staff in carrying out duties, active parents in children's education, supervision of supervisors, and health tests of learners by 'puskesmas' on a regular basis (3) Inhibiting factors and solutions that are less dicipline of parents take and pick up students, and there are some teachers who are late when they come to school. The principal's solution is to inform the parents of the students to take and pick up their children according to the schedule, the principal gives an example of going out early for handshakes with learners, and supervising.
\end{abstract}

Keywords: leadership, transformational, the school principal

\begin{abstract}
Abstrak: Penelitian ini bertujuan untuk mendeskripsikan ciri implementasi kepemimpinan transformasional kepala sekolah, faktor pendukung, dan penghambat serta solusi di SDN Percobaan 1 Malang. Penelitian ini menggunakan pendekatan kualitatif dengan rancangan studi kasus. Teknik pengumpulan data yang digunakan ialah observasi, wawancara dan dokumentasi. Hasil penelitian ini; (1) Ciri implementasi kepemimpinan transformasional Kepala Sekolah; (a) idealisasi pengaruh yaitu menjadi teladan yang baik dan menumbuhkan kebanggaan bagi warga sekolah, (b) motivasi inspirasional yaitu mampu membangkitkan semangat, memberikan perhatian, serta kepercayaan bagi warga sekolahnya, (c) konsiderasi intelektual yaitu memberi penghargaan diri bagi guru yang kreatif dan memberi kesempatan warga sekolah untuk menyelesaikan masalahnya, (d) stimulasi intelektual yaitu mengikut sertakan guru dan staf dalam pelatihan, dan melakukan supervisi kunjungan kelas. (2) Faktor pendukung yaitu kemampuan guru dan staf dalam melaksanakan tugas, orang tua aktif dalam pendidikan anak, supervisi dari pengawas, dan tes kesehatan peserta didik oleh puskesmas secara berkala (3) Faktor penghambat dan solusi yaitu kurang disiplinya orang tua mengantar dan menjemput siswa, dan terdapat beberapa guru yang terlambat saat datang ke sekolah. Solusinya kepala sekolah memberitahukan kepada orang tua siswa agar mengantar dan menjemput anaknya sesuai dengan jadwal, kepala Sekolah memberikan contoh langsung berangkat lebih pagi untuk jabat tangan dengan peserta didik, dan melakukan supervisi.
\end{abstract}

Kata kunci: kepemimpinan, transformasional, kepala sekolah

Kepala sekolah merupakan sosok ideal yang dapat dijadikan sebagai panutan bagi guru dan karyawannya, dipercaya, dihormati, dan mampu mengambil keputusan yang terbaik untuk kepentingan sekolah. Setiap kepemimpinan mempunyai tujuan untuk mengefektifkan suatu organisasi, sehingga menjadi pemimpin yang diinginkan oleh para staf. Zulkarnain (2013:83) 
menjelaskan pengertian kepemimpinan yaitu "kemampuan seseorang untuk mempengaruhi, menggerakkan, dan mengarahkan tingkah laku orang lain atau kelompok untuk mencapai tujuan kelompok dalam situasi tertentu". Sedangkan Handoko (2009:294-295) menyatakan pengertian kepemimpinan adalah "kemampuan yang dipunyai seseorang untuk mempengaruhi orang-orang lain agar bekerja mencapai tujuan dan sasaran" Kepemimpinan kepala sekolah terhadap bawahannya dapat dilihat dari cara bergaul dengan rekan kerjanya ataupun pada saat mengerjakan pekerjaan di sekolah. Kepala sekolah akan melihat dan menilai kinerja bawahannya dengan mengenal, melihat, memahami dan menilainya. Evaluasi terhadap kinerja bawahan dilakukan oleh kepala sekolah untuk mengetahui peningkatan atau penurunan kinerja bawahan dalam melaksanakan pekerjaan di sekolah. Oleh sebab itu, kepala sekolah haruslah sosok yang dinamis, kreatif, dan kompetitif, serta tidak mudah menyerah, patah semangat, dan lemah cita-citanya. Seorang pemimpin harus dapat mempengaruhi bawahannya untuk melaksanakan tugas yang diperintahkan tanpa paksaan sehingga bawahan secara sukarela akan berperilaku dan berkinerja sesuai tuntutan organisasi melalui arahan pimpinannya.

Pemimpin dikatakan transformasional apabila dapat mengubah situasi, mengubah apa yang biasa dilakukan, bicara tentang tujuan yang luhur, memiliki acuan nilai kebebasan, keadilan dan kesamaan. Cavazotte (2013: 1-2) The results suggest that perceived transformational leaders hip is associated with higher levels of task performance and helping behaviors. Berdasarkan penelitian Cavazotte menunjukkan bahwa kepemimpinan transformasional berhubungan dengan lebih tingginya kinerja dan membantu bawahan dalam melaksanakan tugas. Pemimpin yang transformasional akan membuat bawahan melihat bahwa tujuan yang akan dicapai lebih dari sekedar kepentingan pribadinya. Bila ditinjau dari dimensinya, ada beberapa komponen perilaku yang menunjukkan kepemiminan transformasional. Seseorang pemimpin dikatakan menunjukkan kepemimpinan transformasional bila menerapkan komponen perilaku kepemimpinan transformasional, seperti pendapat Wiyono (2013:31) individualized influence mengacu pada perilaku kepemimpinan kepala sekolah yang bisa diakui, dipercaya dan diteladani oleh guru-guru. Inspirational motivation mengacu pada perilaku kepemimpinan kepala sekolah dalam memberikan motivasi tinggi kepada warga sekolah, khususnya anggota sekolah. Intellectual stimulation mengacu pada perilaku kepemimpinan kepala sekolah dalam memberikan stimulasi secara inovatif dan konstruktif. Individualized consideration mengacu pada perilaku pemimpin untuk memberikan perhatian terhadap anggota secara individual. Sedangkan menurut Asmani (2012:50) kepemimpinan transformasional dapat ditunjukkan dengan halhal sebagai berikut; (1) mengidentifikasi dirinya sebagai agen perubahan atau pembaharuan; (2) memiliki sifat pemberani; (3) mempercayai orang lain; (4) bertindak atas dasar sistem nilai (bukan dasar atas kepentingan individu atau atas dasar kepentingan dan desakan kroninya); (5) meningkatkan kemampuan secara terus-menerus sepanjang hayat; (6) memiliki kemampuan untuk menghadapi situasi yang rumit, tidak jelas dan tidak menentu dan; (7) memiliki visi kedepan. Begitu pula pendapat Rohmat (2010:68) pemimpin mentransformasikan dan memotivasi para pengikut dengan; (1) membuat mereka lebih sadar mengenai pentingnya menyelesaikan pekerjaan dengan baik; (2) mendorong mereka untuk lebih mementingkan organisasi atau tim daripada kepentingan diri sendiri. Pemimpin berperan meningkatkan sumber daya manusia yang ada dan berusaha memberikan reaksi yang menimbulkan semangat dan daya kerja yang tinggi bagi anggota, dan yang lebih penting lagi adalah tuntutan untuk memiliki visi yang kuat.

\section{METODE}

Peneliti menggunakan metode penelitian kualitatif untuk menentukan cara mencari, mengumpulkan, mengolah dan menganalisis data hasil penelitian tersebut, sebagaimana Wiyono (2007:72) bahwa penelitian kualitatif merupakan "suatu proses penelitian yang dilakukan secara sistematis dan intensif untuk memperoleh pengetahuan tentang fenomena sosial dengan fenomena sosial itu sendiri". Rancangan penelitian yang digunakan adalah studi kasus deskriptif(descriptive case study) yang mencakup studi kasus eksploratoris dan eksplanatoris yakni Ulfatin (2013:60) bahwa "studi kasus deskriptif 
umumnya digunakan untuk menjawab masalah penelitian yang menyangkut pertanyaan what, how, dan why". Jadi, pelaksanaan penelitian ini adalah untuk mengetahui Implementasi Kepemimpinan Transformasional Kepala Sekolah Dasar Negeri yang ada di SDN Percobaan 1 Malang. Peneliti dalam penelitian ini bertindak sebagai instrumen kunci yang langsung terjun ke lapangan. Oleh karena itu, peran peneliti di lapangan merupakan kunci keberhasilan, sehingga dalam pelaksanaannya dibutuhkan keseriusan dalam penelitian dan juga membutuhkan key informan. Berdasarkan instruksi dari kepala sekolah, informan utama implementasi kepemimpinan transformasional kepala sekolah. Sumber data tersebut diperoleh peneliti secara langsung dari informan yang mengetahui secara langsung mengenai kegiatan kepala sekolah kemudian dikembangkan menggunakan teknik snowball sampling. Teknik pengumpulan data yang dilakukan dalam penelitian ini yaitu observasi, wawancara, dan dokumentasi. Observasi menggunakan observasi. Wawancara menggunakan jenis terstruktur, semi, dan tidak terstruktur. Dokumentasi dilaksanakan melalui pengumpulan file ataupun dokumen yang mendukung penelitian. Analisis data mengadopsi proses yang dilakukan Miles dan Huberman dengan langkah pengumpulan data, reduksi data, display data, dan verifikasi data. Hasil analisis data selanjutnya dicek keabsahannya melalui derajat kepercayaan, keteralihan, ketergantungan, dan konfirmabilitas. Kepercayaan menggunakan triangulasi, pengecekan anggota (member check), perpanjangan waktu pengamatan, meningkatkan ketekunan, serta melalui kecukupan bahan referensi.Keteralihan ditunjukkan penelitimelalui pendiskripsian manajemen pembinaan kesiswaan di lokasi penelitian secara rinci sehingga dapat menjadi informasi dan rujukan apabila terdapat lembaga lain yang ingin menerapkannya. Uji ketergantungan ini dilaksanakan dengan menelusur terhadap keseluruhan proses dan hasil penelitian. Uji konfirmabilitas dapat dilaksanakan secara bersamaan dengan uji ketergantungan dengan menguji hasil dan proses penelitian. Penelitian dilaksanakan melalui tahapan persiapan, pelaksanaan, penulisan laporan.

\section{HASIL}

\section{Ciri Implementasi Kepemimpinan Transformasional Kepala SDN Percobaan 1 Malang}

Ciri kepemimpinan transformasional Idealized influence Kepala Sekolah memiliki beberapa ciri yang pertama Kepala Sekolah mampu menjadi teladan yang baik bagi warga sekolahnya karena Kepala Sekolah selalu datang ke sekolah tepat waktu, sehingga memberikan contoh langsung pada guru dan peserta didik. Kedua Kepala Sekolah menumbuhkan kebanggan kepada pesarta didik dan guru karena semangat dan kegigihan Kepala Sekolah memberi contoh dan menyadarkan langsung warga sekolah bahwa disiplin waktu sangatlah penting. Ciri kepemimpinan transformasional Inspirational motivation Kepala Sekolah memiliki beberapa ciri yang pertama Kepala Sekolah mampu membangkitkan semangat warga sekolah melalui ceramah pagi. Kedua Kepala Sekolah memberi perhatian kepada staf seperti nasihat secara langsung. Ketiga Kepala Sekolah selalu berpartisipasi dalam setiap acara yang ada di sekolah jika Kepala Sekolah berhalangan hadir saat acara Kepala Sekolah selalu memantau melalui group whatsapp atau melalui telepon sekolah. Keempat Kepala Sekolah memberi kepercayaan kepada staf dalam melaksanakan tugas sekolah maupun dinas. Ciri kepemimpinan transformasional Intellectual stimulation Kepala Sekolah memiliki beberapa ciri yang pertama Kepala Sekolah memberikan kepercayaan staf dan guru dalam melaksanakan tugas dari dinas maupun sekolah. Kedua Kepala Sekolah memberi penghargaan diri kepada guru yang melakukan inovasi dan kreatifitas dalam pembelajaran. Ketiga Kepala Sekolah memberi kesempatan staf maupun guru yang melakukan kesalahan untuk menyelesaikan sendiri, namun bila dirasa masalah yang terjadi tidak dapat diselesaikan Kepala Sekolah akan menindak lanjuti melalui musyawarah/rapat. Ciri kepemimpinan transformasional Individualized consideration Kepala Sekolah memiliki beberapa ciri yang pertama Kepala Sekolah melakukan supervisi kunjungan kelas setiap pagi setelah 
melakukan ceramah, kemudian dari supervisi tersebut Kepala Sekolah menindak lanjutinya. Kedua Kepala Sekolah menanyakan bahan ajar guru saat supervisi hal ini dilakukan untuk melihat kemampuan guru dalam menyiapkan bahan ajarnya jika dirasa ada kendala Kepala Sekolah segera menindak lanjutinya. Ketiga Kepala Sekolah mengikutsertakan guru dan staf dalam pelatihan, seminar maupun tugas dari dinas secara bergantian, hal ini diharapkan dapat memberi pengalaman bagi guru dan staf.

\section{Faktor Pendukung dalam Implementasi Kepemimpinan Transformasional Kepala SDN Percobaan 1 Malang.}

Faktor internal bersumber dari dalam sekolah yaitu dari guru, staf dan siswa sebagai berikut; (a) memberdayakan guru dan staf sesuai dengan kemampunnya, (b) guru haruslah linier dalam melakukan pembelajaran, (c) Seorang pemimpin harus bisa memberikan perubahan yang baik bagi sekolahnya lagi, (d) cara berkomunikasi seorang pemimpin harus dapat dimengerti dan dipahami oleh lawan bicaranya. Faktor eksternal bersumber dari luar sekolah yaitu dari orang tua peserta didik, masyarakat, dinas, forum kelas, puskesmas yaitu (a) orang tua, tingkat pendidikan orang tua yang tinggi cenderung kritis pada pendidikan anak sehingga jangan sampai sekolah disorot karena hal kecil, (b) masyarakat, harus menjalin hubungan baik dengan masyarakat karena apa, masyarakat sekitar mau tidak mau pasti berperan serta contohnya saja masyarakat sekitar pasti ikut menjaga keamanan sekolah karena masyarakat sekitar hampir setiap hari mengetahui keadaan sekolah, (c) dinas, peraturan dan informasi dari dinas selalu diturunkan tepat waktu sehingga dapat dengan cepat menindak lanjuti hal tersebut, kemudian supervisi dari pengawas karena dapat membantu dalam hal memimpin Kepala Sekolah, (d) forum kelas, forum kelas ini seperti paguyuban orang tua murid forum ini tempat orang tua walimurid berbagi informasi yang dapat menunjang kemajuan sekolah biasanya forum kelas ini membantu guru saat mengadakan pembelajaran di luar guru hanya memberikan pengarahan saja dan forum kelas yang mengurus biaya dan akomodasinya dan, (e) puskesmas, lembaga ini biasanya membantu tentang pengukuran tinggi dan berat badan, pengecekkan mata, telinga, dan gigi, hal seperti ini dilakukan untuk menjaga kesehatan peserta didik selain itu puskesmas memberikan informasi tentang kesehatan, saat mendapat informasi dari puskesmas mengenai kesehatan, setiap pagi selalu mengumumkan melalui pengeras suara meski tidak berlangsung lama diharapkan warga sekolah waspada dengan hal itu

\section{Faktor Penghambat dan Solusi dalam Implementasi Kepemimpinan Transformasional Kepala SDN Percobaan 1 Malang.}

Kurang disiplinnya orang tua mengantar dan menjemput siswa hal ini berdampak pada kebiasaan siswa, pendidikan dari keluarga sanggatlah penting sehingga alangkah baiknya orangtua mengajarkan kebiasaan yang baik untuk anaknya. Solusi dari Kepala Sekolah memberitahukan kepada orang tua siswa agar mengantar dan menjemput anaknya sesuai dengan jadwal. Terdapat beberapa guru yang belum menyiapkan RPP saat mengajar, sehingga Kepala Sekolah menindak lanjuti dengan memberikan arahan mengenai kesiapan mengajar, harus terlebih membuatan RPP dan memastikan tidak terulang kembali dengan cara guru harus menyerahkan RPP sebelum pembelajaran dimulai. Sebelum melakukan kegiatan pembelajaran yang harus dilakukan guru terlebih dahulu menyiapkan RPP (Rencana Pelaksanaan Pembelajaran) sehingga pembelajaran yang dilakukan dapat berjalan maksimal. Terdapat beberapa guru yang terlambat saat datang ke sekolah, Kepala Sekolah memberikan contoh langsung seperti berangkat lebih pagi untuk jabat tangan dengan peserta didik hal ini secara tidak langsung Kepala Sekolah memberikan contoh pembiasaan bagi guru maupun peserta didik untuk lebih menghargai waktu dan berangkat ke sekolah lebih awal.

\section{PEMBAHASAN}

\section{Ciri Implementasi Kepemimpinan Transformasional Kepala SDN Percobaan 1 Malang}

Kepemimpinan transformasional akan memberikan pengaruh postif pada hubungan antara kepala sekolah dan warga sekolah, dengan 
konsep kepemimpinan transformasional warga sekolah akan merasa kagum, bangga, loyal dan hormat kepada kepala sekolah serta termotivasi untuk mengerjakan pekerjaan dengan hasil yang melebihi target. Kepala Sekolah merupakan sosok ideal yang dapat dijadikan sebagai panutan bagi guru dan karyawannya, dipercaya, dihormati dan mampu mengambil keputusan yang terbaik untuk kepentingan sekolah. Kepemimpinan transformasional Idealized influence kepala sekolah memiliki beberapa ciri yang pertama Kepala Sekolah mampu menjadi teladan yang baik bagi warga sekolahnya karena Kepala Sekolah selalu datang ke sekolah tepat waktu, sehingga memberikan contoh langsung pada guru dan peserta didik. Kedua Kepala Sekolah menumbuhkan kebanggan kepada pesarta didik dan guru karena semangat dan kegigihan Kepala Sekolah memberi contoh dan menyadarkan langsung warga sekolah bahwa disiplin waktu sangatlah penting.

Temuan peneliti dilapangan sesuai dengan pendapat Bass dan Aviola (dalam Komariah dan Triatna, 2010:79) idealiced influence, yang dijelaskan sebagai perilaku yang menghasilkan rasa hormat (respect) dan rasa percaya diri (trust) dari orang yang dipimpinya. Idealiced influence mengandung makna saling berbagi resiko melalui pertimbangan kebutuhan para staf di atas kebutuhan pribadi dan prilaku moral secara etis. Begitu pula dengan pendapat Felfe dan Schyns (dalam Wiyono ,2007:32) idialized influence mengacu pada perilaku pimpinan yang dapat diteladani oleh bawahan. Pimpinan diakui sebagai model peranan, pimpinan menunjukkan nilai-nilai, pelayanan dan produk ideal, mendemonstrasikan komitmen dengan standar moral yang tinggi, serta memiliki pengaruh terhadap bawahan. Suryanto (dalam Asmani, 2012:54) ciri kepemimpinan transformasional idialized influence, meliputi; (1) menunjukkan keyakinan diri yang kuat; (2) menghadirkan diri disaat-saat sulit; (3) menunjukkan nilai yang penting; (4) menunjukan kebanggaan; (5) meyakini visi, membanggakan keutamaan visi itu, dan secara pribadi bertanggung jawab penuh pada tindakan; (6) menunjukkan sense of purpose; dan (7) meneladani ketekunan alam semesta. Teori tersebut dipaparkan sangat rinci namun dari temuan penelitian yang peneliti temukan sedikit banyak sudah mencangkup ke tujuh ciri yang telah dijelaskan. Sehingga dapat disimpulkan temuan penelitian yang peneliti temukan sesuai dengan beberapa pendapat ahli tersebut. Karena inti dari idialized influence kepala sekolah harus dapat menjadi model peranan bagi guruguru dalam bertindak jujur, dapat memberikan contoh yang baik dalam melaksanakan tugas, lebih mementingkan kepentingan organisasi daripada kepentingan pribadi, serta mendapatkan kepercayaan dan pengauan dari bawahan. Dengan demikian kepala sekolah akan memiliki pengaruh yang kuat terhadap anggota serta bisa menggerakkan semua anggota, baik guru atau staf sekolah lainnya, kearah tercapainya tujuan organisasi sekolah.

Kepala Sekolah dapat memotivasi seluruh guru dan karyawannya untuk memiliki komitmen terhadap visi organisasi dan mendukung semangat tiam dalam mencapai tujuan-tujuan pendidikan di sekolah. Kepemimpinan transformasional Inspirational motivation Kepala Sekolah memiliki beberapa ciri yang pertama Kepala Sekolah mampu membangkitkan semangat warga sekolah melalui ceramah pagi. Kedua Kepala Sekolah memberi perhatian kepada staf seperti nasihat secara langsung. Ketiga Kepala Sekolah selalu berpartisipasi dalam setiap acara yang ada di sekolah jika Kepala Sekolah berhalangan hadir saat acara Kepala Sekolah selalu memantau melalui group whatsapp atau melalui telepon sekolah. Keempat Kepala Sekolah memberi kepercayaan kepada staf dalam melaksanakan tugas sekolah maupun dinas. Penemuan tersebut sesuai dengan pendapat Bass dan Aviola (dalam Komariah dan Triatna, 2010:79) inspirational motivation, tercermin dalam perilaku yang senantiasa menyediakan tantangan bagi pekerjaan yang dilakukan staf dan memerhatikan makna pekerjaan bagi staf. Pemimpin menunjukkan atau mendemonstrasikan komitmen terhadap sasaran organisasi melalui perilaku yang dapat diobservasi staf. Pemimpin adalah seorang motivator yang bersemangat untuk terus membangkitkan antusasme dan optimism staf. Dijelaskan pula secara rinci oleh Suryanto (dalam Asmani, 2012:54) ciri kepemimpinan transformasional inspirational motivation meliputi; (1) menginspirasi bawahan mencapai kemungkinan-kemungkinan yang tidak terbayangkan; (2) menyelaraskan tujuan individu dan organisasi; (3) memandang ancaman dan 
persoalan sebagai kesempatan untuk belajar dan berprestasi; (4) menggunakan kata-kata yang membangkitkan semangat; (5) menggunakan simbol-simbol; (6) menampilkan visi yang menggairahkan; (7) menantang bawahan dengan standar yang tinggi; (8) berbicara optimis dan antusias; (9) memberikan dukungan terhadap apa yang perlu dilakukan; (10) memberikan makna pada apa yang dilakukan; (11) menjadi role mode bagi bawahan; (12) menciptakan budaya bawahan kesalahan yang terjadi dipandang sebagai pengalaman belajar; (13) menggunakan metafora, dan; (14) menjadi mentor. Ketiga belas tersebut sudah beberapa ciri yang mencangkup pada temuan peneliti sehingga dapat dikatakan bahwa kepala sekolah sudah memberikan motivasi tinggi kepada anggota sekolah, yakni dengan menerapkan nilai-nilai dan cita-cita yang tinggi selain itu mengembangkan visi, misi dan tujuan organisasi sekolah, serta meningkatkan optimis warga sekolah dalam mencapai visi, misi dan tujuan organisasi.

Kepala Sekolah dapat menumbuhkan kreativitas dan inovasi di kalangan guru dan stafnya dengan mengembangkan pemikiran kritis dan pemecahan masalah untuk menjadikan sekolah ke arah yang lebih baik. Kepemimpinan transformasional Intellectual stimulation Kepala Sekolah memiliki beberapa ciri yang pertama kepala sekolah memberikan kepercayaan staf dan guru dalam melaksanakan tugas dari dinas maupun sekolah. Kedua kepala sekolah memberi penghargaan diri kepada guru yang melakukan inovasi dan kreatifitas dalam pembelajaran. Ketiga kepala sekolah memberi kesempatan staf maupun guru yang melakukan kesalahan untuk menyelesaikan sendiri, namun bila dirasa masalah yang terjadi tidak dapat diselesaikan kepala sekolah akan menindak lanjuti melalui musyawarah/rapat. Temuan tersebut sesuai dengan Bass dan Aviola (dalam Komariah dan Triatna, 2010:79) intellectual stimulation, yaitu pemimpin yang mempraktikkan inovasi-inovasi. Sikap dan perilaku kepemimpinanya didasarkan pada ilmu pengetahuan yang berkembang dan secara intelektual ia mampu menerjemahkannya dalam bentuk kinerja yang produktif. Sebagai intelektual, pemimpin senantiasa menggali ideide baru dan solusi yang kreatif dari para staf dan tidak lupa selalu mendorong staf mempelajari dan mempraktikkan pendekatan baru dalam melakukan pekerjaan. Menurut Bell dan Cheng (dalam Wiyono, 2007:36) dikemukakan bahwa intellectual stimulation menunjukkan pada kemampuan pimpinan untuk menstimulasi bawahan agar lebih kreatif dalam berfikir dan memecahkan masalah. Begitu pula pendapat dalam Hoy dan Miskel (dalam Wiyono, 2007:37) intellectual stimulation berkaitan dengan masalah kreatifitas, pemimpin mampu menstimulasi anggota menjadi kreatif dan inovatif. Pemimpin selalu berussaha untuk mengembangkan programprogram baru, serta mendorong anggota untuk kreatif mengembangkan program, prosedur, atau cara-cara baru yang lebih baik dalam melaksanakan tugas atau memecahkan masalah. Pimpinan juga bersikap terbuka terhadap anggota dalam melaksanakan perubahan kea rah yang lebih baik. Dari ketiga pendapat ahli tersebut sudah mencakup semua penemuan peneliti di lapangan sehingga temuan peneliti tersebut sudah sesuai dengan ketiga pendapat ahli namun dipaparan lebih rinci lagi dari pendapat Suryanto (dalam Asmani, 2012:54) menyatakan bahwa ciri kepemimpinan transformasional intellectual stimulation meliputi; (1) mempertanyakan status quo; (2) mendorong pemanfaatan imajinasi; (3) mendorong penggunaan intuisi yang dipandu dengan logika; (4) mengajak melihat prespektif baru; (5) memakai simbol-simbol pendukung inovasi; (6) mempertanyakan asumsi lama; (7) mempertanyakan tradisi usang; dan (8) mempercayakan kepercayaan yang melekat pada organisasi. Berdasaran dari pendapat tersebut dapat dilihat bahwa intellectual stimulation menekankan pada stimulasi, sehingga kepala sekolah diharuskan mampu menstimulasi bawahan agar dapat mengekspresikan ideidenya dalam mencapai tujuan organisasi. Kepala sekolah mengenalkan metode atau caracara baru yang lebih baik dalam memecahkan masalah atau melaksanakan tugas sehari-hari. Tidak hanya itu saja kepala sekolah juga harus memberikan dorongan kepada bawahan, baik guru-guru maupun staf sekolah lainya, untuk mengembangkan program atau metode baru dalam melaksanakan tugas.

Kepala Sekolah dapat bertindak sebagai pelatih dan penasihat bagi guru dan stafnya. Kepemimpinan transformasional Individualized consideration Kepala Sekolah memiliki beberapa ciri yang pertama kepala sekolah melakukan 
supervisi kunjungan kelas setiap pagi setelah melakukan ceramah, kemudian dari supervisi tersebut kepala sekolah menindak lanjutinya. Kedua kepala sekolah menanyakan bahan ajar guru saat supervisi hal ini dilakukan untuk melihat kemampuan guru dalam menyiapkan bahan ajarnya jika dirasa ada kendala kepala sekolah segera menindak lanjutinya. Ketiga kepala sekolah mengikutsertakan guru dan staf dalam pelatihan, seminar maupun tugas dari dinas secara bergantian, hal ini diharapkan dapat memberi pengalaman bagi guru dan staf. Temuan peneliti tersebut sesuai dengan Suryanto (dalam Asmani, 2012:54) ciri kepemimpinan transformasional individualized consideration meliputi; (1) merenung, memikirkan, dan mengidentifikasi kebutuhan individual; (2) mengidentifikasi kemampuan bawahan; (3) memberi kesempatan belajar; (4) mendelegasikan wewenang; (5) melatih dan memberikan umpan balik pengembangan diri; (6) mendengarkan dengan perhatian penuh; dan (7) memberdayakan bawahan. Menurut Bass dan Aviola (dalam Komariah dan Triatna, 2010:79) individualized consideration, pemimpin merefleksikan dirinya sebagai seorang yang penuh perhatian dalam mendengarkan dan menindaklanjuti keluhan, ide, harapan-harapan, dan segala masukan yang diberikan staf. Begitu pula pendapat dari Beach dan Reinharzt (dalam Wiyono, 2007:39) mengemukakan bahwa individualized consideration dapat ditunjjukkan dengan memberikan dukungan, perhatian, dorongan, dan sumber-sumber yang dibutuhkan, sehingga anggota melakukan yang terbaik. Sehingga dapat disimpulkan bahwa dari penemuan peneliti sesuai dengan beberapa pendapat ahli, namun pada pendapat Suryanto yang dipaparkan secara rinci, peneliti tidak mencari seluruh ciri yang dipaparkan. Peneliti hanya melihat dari kebiasaan kepala sekolah melalui observasi, pendapat dari berbagai pihak melalui wawancara dan dokumentasi. Namun menurut peneliti penemuan tersebut sudah mencakup inti dari individualized consideration, karena ciri kepemimpinan transformasional individualized consideration mengacu pada perilaku pimpinan untuk memberikan pertimbangan dan perhatian terhadap anggota secara individual.

\section{Faktor Pendukung dalam Implementasi Kepemimpinan Transformasional Kepala SDN Percobaan 1 Malang.}

Faktor pendukung dari berbagai pihak untuk kepala sekolah dalam menjalankan kepemimpinanya dapat mengintensifkan kepemimpinan yang dijalankan guna memicu motivasi kerja guru dan staf agar lebih efektif lagi. Faktor internal bersumber dari dalam sekolah yaitu dari guru, staf dan siswa sebagai berikut; (a) memberdayakan guru dan staf sesuai dengan kemampunnya, (b) guru haruslah linier dalam melakukan pembelajaran, (c) Seorang pemimpin harus bisa memberikan perubahan yang baik bagi sekolahnya, (d) cara berkomunikasi seorang pemimpin harus dapat dimengerti dan dipahami oleh lawan bicaranya. Faktor eksternal bersumber dari luar sekolah yaitu dari orang tua peserta didik, masyarakat, dinas, forum kelas, puskesmas (a) orang tua, tingkat pendidikan orang tua yang tinggi cenderung kritis pada pendidikan anak sehingga jangan sampai sekolah disorot karena hal kecil, (b) masyarakat, menjalin hubungan baik dengan masyarakat karena apa, masyarakat sekitar mau tidak mau pasti berperan serta contohnya saja masyarakat sekitar pasti ikut menjaga keamanan sekolah karena masyarakat sekitar hampir setiap hari mengetahui keadaan sekolah, (c) dinas, peraturan dan informasi dari dinas selalu diturunkan tepat waktu sehingga dapat dengan cepat kepala sekolah menindaklanjuti hal tersebut, kemudian supervisi dari pengawas sangat bagus karena dapat membantu apa lagi dalam hal memimpin Kepala Sekolah, (d) forum kelas, forum kelas ini seperti paguyuban orang tua murid forum ini tempat orang tua walimurid berbagi informasi yang dapat menunjang kemajuan sekolah biasanya forum kelas ini membantu guru saat mengadakan pembelajaran di luar guru hanya memberikan pengarahan saja dan forum kelas yang mengurus biaya dan akomodasinya, (e) puskesmas, lembaga ini biasanya membantu tentang pengukuran tinggi dan berat badan, pengecekkan mata, telinga, dan gigi, hal seperti ini dilakukan untuk menjaga kesehatan peserta didik selain itu puskesmas memberikan informasi tentang kesehatan, saat mendapat informasi dari puskesmas mengenai 
kesehatan, kepala sekolah setiap pagi selalu mengumumkan melalui pengeras suara meski tidak berlangsung lama kepala sekolah berharap warga sekolah waspada dengan hal itu.

Berdasarkan dari temuan tersebut dapat dianalisis bahwa hasil penemuan peneliti sesuai dengan pendapat ahli Menurut Mulyasa (2009:126) kepemimpinan kepala sekolah yang efeketif dapat dilihat berdasarkan kriteria mampu memberdayakan guru-guru untuk melaksanakan proses pembelajaran dengan baik, lancar, dan produktif; dapat menyelesaikan tugas dan pekerjaan sesuai dengan waktu yang telah ditetapkan; mampu menjalin hubungan yang harmonis dengan masyarakat sehingga dapat melinatkan mereka secara efektif dalam rangka mewujudkan tujuan sekolah dan pendidikan; berhasil menerapkan prinsip kepemimpinan yang sesuai dengan tingkat kedewasaan guru dan pegawai lain di sekolah; bekerja dengan tim manajemen; serta berhasil mewujudkan tujuan sekolah secara produktif sesuai dengan ketentuan yang telah ditetapkan. Berdasarkan pendapat ahli tersebut dapat dilihat bahwa kepala sekolah SDN Percobaan 01 Malang sudah menerapkan beberapa faktor pendukung yang dipaparkan oleh peneliti sehingga kepemimpinan kepala sekolah yang dijalankan berjalan dengan efektif.

Pendapat lain dikemukakan oleh Mittal (2015:26) Transformational leadership style would be more acceptable in collectivistic and tight societies. These insights have practical implications for design of leadership intervention programs for businesses spanning more than one culture. Mittal menjelaskan bahwa model gaya kepemimpinan transformasional dapat diterima oleh masyarakat luas dari pada gaya transaksional, hal ini dapat dibuktikan pemimpin transformasional dapat merancang progam kegiatan usaha yang mencangkup masyarakat luas bahkan budaya lain. Begitu pula pedapat dari Asmani (2012:53) salah satu inti aktifitas kepemimpinan transformasional adalah melakukan transformasi. Kepemimpinan transformasional menuntut kemampuan kepala sekolah dalam berkomunikasi, terutama komunikasi persuasif. Kepala sekolah yang mampu berkomunikasi secara persuasif dengan komunitasnya akan menjadi faktor pendukung dalam proses transformasi kepemimpinanya. Sebaliknya, pemimpin yang tidak mampu berkomunikasi secara persuasif dengan komunitasnya akan menjadi penghambat transformasi kepemimpinanya. Sehingga dapat dilihat dari berbagai pihak kepala sekolah mendapatkan dukungan membuktikan bahwa kepala sekolah juga mampu berkomunikasi secara baik terhadap lawannya, dan dapat menjadi keunggulan tersendiri dalam menjalankan kepemimpinan yang dijalankan

\section{Faktor Penghambat dan Solusi dalam Implementasi Kepemimpinan Transformasional Kepala SDN Percobaan 1 Malang.}

Kepala sekolah merupakan penggerak kebijakan sekolah yang akan menentukan bagaimana tujuan sekolah, namun setiap keberhasilan kepemimpinan kepala sekolah pasti terdapat hambatan yang terjadi. Hambatan serta solusi yang diambil yaitu, kurang disiplinnya orang tua mengantar dan menjemput siswa hal ini berdampak pada kebiasaan siswa, pendidikan dari keluarga sanggatlah penting sehingga alangkah baiknya orangtua mengajarkan kebiasaan yang baik untuk anaknya. Solusi dari Kepala Sekolah memberitahukan kepada orang tua siswa agar mengantar dan menjemput anaknya sesuai dengan jadwal. Terdapat beberapa guru yang belum menyiapkan RPP saat mengajar, sehingga kepala sekolah menindak lanjuti dengan memberikan arahan mengenai kesiapan mengajar, harus terlebih membuatkan RPP dan memastikan tidak terulang kembali dengan cara guru harus menyerahkan RPP sebelum pembelajaran dimulai. Sebelum melakukan kegiatan pembelajaran yang harus dilakukan guru terlebih dahulu menyiapkan RPP (Rencana Pelaksanaan Pembelajaran) sehingga pembelajaran yang dilakukan dapat berjalan maksimal. Terdapat beberapa guru yang terlambat saat datang ke sekolah, kepala sekolah memberikan contoh langsung seperti berangkat lebih pagi untuk jabat tangan dengan peserta didik hal ini secara tidak langsung kepala sekolah memberikan contoh pembiasaan bagi guru maupun peserta didik untuk lebih menghargai waktu dan berangkat ke sekolah lebih awal.

Kendala yang terjadi pada temuan penelitian adalah banyak terdapat dari warga sekolahnya seperti kedisiplinan, keterlambatan, ketertiban 
namun dari beberapa temuan tersebut sesuai dengan pendapat Asmani (2012:215) kendalakendala yang terjadi dalam kepemimpinan yaitu terdapat 2 macam yang pertama faktor external dan internal faktor-faktor tersebut yaitu; (1) Internal yaitu lemahnya semangat belajar, sibuk dengan kegiatan lain, otoriter dan sentralistis, sulit diajak kerjasama, dan miskin kreatifitas, sedangkan (2) eksternal yaitu tidak ada pembinaan intensif dari atasan, bawahan yang berorientasi materealistis, apatisme para guru terhadap program yang ada, dan orang tua yang pasif. Namun tidak sesuai dengan pendapat Soekanto dan Hani (dalam Saffandi, 2014) memberi beberapa alasan terjadinya penolakan terhadap perubahan, antara lain karena: (1) kepentingan pribadi yang picik (kekuasaan, keamanan, uang, dan lain-lain); (2) kesalahpahaman dan kekurangpercayaan; (3) penilaian yang berbeda terhadap suatu usulan perubahan; (4) toleransinya rendah terhadap perubahan. Karena pendapat tersebut lebih menekankan pada pemimpin tetapi yang terjadi dilapangan hambatan terdapat pada warga sekolahnya bukan kepala sekolahnya.

\section{PENUTUP}

\section{Simpulan}

Kesimpulan dari penelitian ini adalah; (1) ciri implementasi kepemimpinan transformasional Kepala SDN Percobaan 1 Malang yaitu; (a) idealisasi pengaruh (Idealized influence) yaitu kepala sekolah menjadi teladan yang baik dan menumbuhkan kebanggaan bagi warga sekolah, (b) motivasi inspirasional (Inspirational motivation) yaitu kepala sekolah berpartisipasi dalam kegiatan sekolah, dan kepala sekolah mampu membangkitkan semangat, memberikan perhatian, serta kepercayaan bagi warga sekolahnya, (c) konsiderasi intelektual (Individualized consideration yaitu kepala sekolah kepala sekolah memberi penghargaan diri bagi guru yang kreatif dan kepala sekolah memberi kesempatan warga sekolah untuk menyelesaikan masalahnya sendiri, (d) stimulasi intelektual (Intellectual stimulation) yaitu kepala sekolah mengikutsertakan guru dan staf dalam pelatihan, kepala sekolah melakukan supervisi kunjungan kelas dan selalu menanyakan bahan ajar. (2) Faktor pendukung dari kepemimpinan transformasional didapat faktor internal dan eksternal, yaitu; (a) faktor internal bersumber dari guru, staf dan siswa, (b) faktor eksternal bersumber dari luar sekolah yaitu dari orang tua peserta didik, masyarakat, Dinas Pendidikan, forum kelas, puskesmas. (3) Faktor penghambat dan solusi yaitu kurang disiplinya orang tua mengantar dan menjemput siswa, terdapat bebrapa guru yang belum menyiapkan RPP saat mengajar, dan terdapat beberapa guru yang terlambat saat datang ke sekolah. Solusinya adalah kepala Sekolah memberitahukan kepada orang tua siswa agar mengantar dan menjemput anaknya sesuai dengan jadwal, kepala Sekolah menindak lanjuti dengan memberikan arahan mengenai kesiapan mengajar, harus terlebih membuat RPP dan memastikan tidak terulang kembali, kepala Sekolah memberikan contoh langsung seperti berangkat lebih pagi untuk jabat tangan dengan peserta didik

\section{Saran}

Berdasarkan beberapa hasil analisi yang telah dijalankan beserta kesimpulan yang berhasil diperoleh oleh peneliti, berikut ini merupakan saran yang diberikan oleh peneliti oleh peneliti; pertama bagi Kepala Sekolah SDN Percobaan 1 Malang yaitu Kepala Sekolah perlu mengintensifkan perilaku kepemimpinan transformasional guna memicu motivasi kerja guru dan staf agar lebih baik lagi. Hal ini penting mengingat karakteristik masyarakat yang selalu melihat perilaku pemimpinya dalam mengerjakan sesuatu. Kedua bagi Guru dan StafSDN Percobaan 1 Malang yaitu Guru dan staf diharapkan mampu mempertahankan motivasi kerja maupun meningkatkan keterlibatan untuk mendukung kepemimpinan transformasional kepala sekolah. Ketiga bagi peserta didik dan orang tua yaitu peserta didik hendaknya selalu menaati peraturan tata tertib sekolah dan bagi orang tua hendaknya selalu memberikan dukungan pelaksanaan tata tertib yang ada di sekolah untuk mendukung kepemimpinan transformasional kepala sekolah. Keempat bagi peneliti lain yaitu disarankan agar melakukan tindak lanjut dari penelitian ini berupa melakukan penelitian mengenai kepemimpinan transformasional yang lebih efektif untuk diterapkan di lembaga pendidikan. 


\section{DAFTAR RUJUKAN}

Asmani, M. J. 2012. Tips Menjadi Kepala Sekolah Professional. Jogjakarta: DIVA Press.

Cavazotte, F. 2013. Transformational Leaders and Work Performance: The

Mediating Roles of Identification and Selfefficacy. BAR (Brazilian Administration Review) Rio de Janeiro, (Online), 10 (4):1-2, (http://www. anpad.org.br/bar), diakses 30 Desember 2016.

Handoko, H. T. 2009. Manajemen (Edisi 2). Yogyakarta: BPFE UGM.

Komariah dan Triatna. 2010. Visionary Leadership Menuju Sekolah Efektif. Jakarta: PT Bumi Aksara.

Mittal, R. 2015. Charismatic and Transformational Leadership Styles: A Cross-Cultural Perspective. International Journal of Business and Management, (Online), 10 (3):26-27,(http:// dx.doi.org/10.5539/ijbm.v10n3p26), diakses 30 Desember 2016

Mulyasa. 2009. Manajemen Berbasis Sekolah: Konsep, Strategi, dan Implementasi. Bandung: PT Remaja Rosdakarya.
Rohmat. 2010. Kepemimpinan Pendidikan Konsep dan Aplikasi. Purwokerto: STAIN Press.

Saffandi.2014.TeoriKepemimpinanTransformasional. (Online) (http://imammukhlisaffandi.blogspot. co.id/2014/12/transformational-leadershipuntuk.html) Diunduh 15 Februari 2016.

Ulfatin, N. 2013. Metode Penelitian Kualitatif di Bidang Pendidikan. Malang: Bayumedia Publishing.

Wiyono, B.B. 2007. Metodologi Penelitian (Pendekatan Kuantitatif, Kualitatif, dan Action Research). Malang: Fakultas Ilmu Pendidikan Universitas Negeri Malang.

Wiyono, B.B. 2013. Kepemimpinan Transformasional Kepala Sekolah ( Konsep, Pengukuran, dan Pengembangan). Malang: Fakultas Ilmu Pendidikan Universitas Negeri Malang.

Wiyono.B.B. 2007. Self Evaluation Kepemimpinan Transformasional Kepala Sekolah Dasar. Disertasi. Yogyakarta: Universitas Negeri Yogyakarta

Zulkarnain, W. 2013. Dinamika Kelompok: Latihan Kepemimpinan Pendidikan. Jakarta: Bumi Aksara. 